University of Nebraska - Lincoln

DigitalCommons@University of Nebraska - Lincoln

\title{
An improved colorimetric method for chlorine dioxide and chlorite ion in drinking water using lissamine green $B$ and horseradish peroxidase
}

\author{
Barry V. Pepich \\ Shaw Environmental, Inc., pepich.barry@epa.gov \\ Teri A. Dattilio \\ Shaw Environmental, Inc. \\ Patricia S. Fair \\ U.S. EPA \\ David J. Munch \\ U.S. EPA \\ Gilbert Gordon \\ Miami University - Oxford \\ See next page for additional authors
}

Follow this and additional works at: https://digitalcommons.unl.edu/usepapapers

Pepich, Barry V.; Dattilio, Teri A.; Fair, Patricia S.; Munch, David J.; Gordon, Gilbert; and Körtvélyesi, Zsolt, "An improved colorimetric method for chlorine dioxide and chlorite ion in drinking water using lissamine green B and horseradish peroxidase" (2007). U.S. Environmental Protection Agency Papers. 174. https://digitalcommons.unl.edu/usepapapers/174

This Article is brought to you for free and open access by the U.S. Environmental Protection Agency at DigitalCommons@University of Nebraska - Lincoln. It has been accepted for inclusion in U.S. Environmental Protection Agency Papers by an authorized administrator of DigitalCommons@University of Nebraska - Lincoln. 


\section{Authors}

Barry V. Pepich, Teri A. Dattilio, Patricia S. Fair, David J. Munch, Gilbert Gordon, and Zsolt Körtvélyesi 


\title{
An improved colorimetric method for chlorine dioxide and chlorite ion in drinking water using lissamine green $\mathrm{B}$ and horseradish peroxidase
}

\author{
Barry V. Pepich ${ }^{\mathrm{a}, *}$, Teri A. Dattilio ${ }^{\mathrm{a}, 1}$, Patricia S. Fair ${ }^{\mathrm{b}}$, David J. Munch ${ }^{\mathrm{b}}$, \\ Gilbert Gordon $^{\mathrm{c}}$, Zsolt Körtvélyesi ${ }^{\mathrm{c}}$ \\ a Shaw Environmental, Inc., 26 W. Martin Luther King Drive, Cincinnati, OH 45268, United States \\ ${ }^{\mathrm{b}}$ U.S. EPA Office of Ground Water and Drinking Water, Technical Support Center, \\ 26 W. Martin Luther King Drive, Cincinnati, OH 45268, United States \\ ${ }^{\mathrm{c}}$ Department of Chemistry, Miami University, Oxford, OH, United States
}

Received 7 March 2007; received in revised form 15 May 2007; accepted 4 June 2007

Available online 8 June 2007

\begin{abstract}
Lissamine Green B (LGB) was carefully selected as a potential candidate for the development of a new U.S. Environmental Protection Agency (EPA) method that is intended for use at water utilities to determine chlorine dioxide $\left(\mathrm{ClO}_{2}\right)$ in drinking water. Chlorine dioxide reacts with LGB in aqueous solution to decrease the absorbance of LGB in direct proportion to the $\mathrm{ClO}_{2}$ concentration. LGB was confirmed to have adequate sensitivity, and to suffer less interference than other dyes reported in the literature. The stoichiometry for the reaction between $\mathrm{LGB}$ and $\mathrm{ClO}_{2}$ was found not to be 1:1 and is dependent on the LGB concentration. This required calibration of each LGB stock solution and prompted the investigation of alternate means of calibration, which utilized a horseradish peroxidase (HRP)-catalyzed conversion of chlorite ion $\left(\mathrm{ClO}_{2}{ }^{-}\right)$to $\mathrm{ClO}_{2}$. This approach allowed the simultaneous determination of $\mathrm{ClO}_{2}{ }^{-}$concentration, which is also required each day at water plants that use $\mathrm{ClO}_{2}$. Studies were conducted to characterize and carefully optimize the $\mathrm{HRP}$-conversion of $\mathrm{ClO}_{2}{ }^{-}$to $\mathrm{ClO}_{2}$ in order to yield reaction conditions that could be accomplished in less than $30 \mathrm{~min}$ at modest cost, yet meet EPA's sensitivity and robustness requirements for routine monitoring. An assessment of method detection limit, linearity and slope (or sensitivity), precision, and accuracy in finished drinking water matrices indicated that this approach was suitable for publication as EPA Method 327.0.
\end{abstract}

Published by Elsevier B.V.

Keywords: Chlorine dioxide and chlorite analysis; Drinking water; Lissamine green B; Horseradish peroxidase

\section{Introduction}

Chlorine dioxide $\left(\mathrm{ClO}_{2}\right)$ is used for many purposes during the production of drinking water, such as control of taste and odor problems, removal of iron and manganese, and a disinfection strategy for control of halogenated organic disinfection byproducts. When $\mathrm{ClO}_{2}$ reacts with constituents in the water, the anions chlorite, chloride, and chlorate are formed [1]. Due to potential adverse health effects associated with short-term exposure to $\mathrm{ClO}_{2}$ and chlorite ion $\left(\mathrm{ClO}_{2}{ }^{-}\right)$[2], the U.S. Environmental Protection Agency (EPA) established a maximum residual

\footnotetext{
* Corresponding author. Tel.: +1 513569 7439; fax: +1 5135697837.

E-mail address: pepich.barry@epa.gov (B.V. Pepich).

1 Present address: Teledyne Tekmar, 4736 Socialville Foster Rd, Mason, OH 45040, USA.
}

disinfectant level (MRDL) of $0.8 \mathrm{mg} \mathrm{L}^{-1}$ for $\mathrm{ClO}_{2}$ and a maximum contaminant level (MCL) of $1.0 \mathrm{mg} \mathrm{L}^{-1}$ for $\mathrm{ClO}_{2}{ }^{-}$in drinking water as part of the Stage 1 Disinfectant/Disinfection Byproducts (D/DBP) Rule [3].

Drinking water plants that use chlorine dioxide are required to test the water entering their distribution system on a daily basis using an EPA-approved method to confirm that their water is below the MRDL and MCL for $\mathrm{ClO}_{2}$ and $\mathrm{ClO}_{2}{ }^{-}$. Standard Method 4500- $\mathrm{ClO}_{2} \mathrm{D}$ [4] involves the reaction between $N, N^{\prime}$-diethyl- $p$-phenylenediamine (DPD) and $\mathrm{ClO}_{2}$ to form an oxidized product that is measured at $550 \mathrm{~nm}$. Limitations of this method include the potential interference posed by manganese (4), and the potential interference caused by free available chlorine (FAC) even in the presence of the masking reagent glycine, which is used to suppress this interference [5]. Standard Method $4500-\mathrm{ClO}_{2} \mathrm{E}$, involves a successive amperometric 
titration procedure to determine $\mathrm{ClO}_{2}$ and $\mathrm{ClO}_{2}{ }^{-}$concentrations [6]. Method 4500- $\mathrm{ClO}_{2} \mathrm{E}$ is subject to interferences from manganese, copper, and nitrate, which are commonly found in drinking waters.

While the methods approved for daily monitoring under the Stage 1 D/DBP Rule were deemed adequate by EPA at the time of rule promulgation, EPA initiated studies aimed at developing a new method for $\mathrm{ClO}_{2}$ that might offer improved selectivity and simplicity. A comprehensive search of the literature identified four different dyes that had been investigated as potential alternative methods to determine chlorine dioxide in water-acid chrome violet $\mathrm{K}(\mathrm{ACVK})$, amaranth, chlorophenol red (CPR) and lissamine green $\mathrm{B}$ (LGB) [7-15]. Each involves a colorimetric technique similar to the DPD method. Amaranth and ACVK were reported to have interferences with permanganate, which is commonly used for drinking water treatment. CPR was reported to exhibit an interference with chlorite, which is a serious limitation since chlorite is formed during disinfection with $\mathrm{ClO}_{2}$. All methods showed some interference associated with colored waters. LGB was selected for evaluation because it appeared to have the least number of potential interferences and because it offered the most sensitivity.

The reaction of $\mathrm{HRP}$ with $\mathrm{ClO}_{2}{ }^{-}$was originally investigated over 30 years ago [16]. Horseradish peroxidase was reported to react with $\mathrm{ClO}_{2}{ }^{-}$to form another reactive molecule that was capable of chlorinating monochlorodimedone [17]. The intermediate produced, however, was the subject to debate. One group provided evidence that the reactive intermediate is $\mathrm{ClO}_{2}$ [16,18-20] and proposed the following reaction [18].

$5 \mathrm{HClO}_{2} \rightarrow 4 \mathrm{ClO}_{2}+\mathrm{Cl}^{-}+2 \mathrm{H}_{2} \mathrm{O}+\mathrm{H}^{+}$

A second group presented data supporting the production of hypochlorite ion rather than $\mathrm{ClO}_{2}$ by the reaction of HRP and $\mathrm{ClO}_{2}{ }^{-}[17,21]$.

Because this enzymatic reaction offered the potential to develop a single method to analyze both $\mathrm{ClO}_{2}$ and $\mathrm{ClO}_{2}{ }^{-}$, a number of experiments were designed to demonstrate the feasibility of using LGB to measure the $\mathrm{ClO}_{2}$ formed by HRP. Data from these studies supported preliminary feasibility, and warranted additional studies to determine if objectives for a viable compliance method could be met. These objectives include: (i) sufficient precision at low concentration to yield a method detection limit for both $\mathrm{ClO}_{2}$ and $\mathrm{ClO}_{2}{ }^{-}$that are at least a factor of five below their MRDL and MCL; (ii) precision and accuracy at concentrations near the MRDL/MCL that would allow the users to routinely achieve quality assurance recovery criteria (which are typically set at 70-130\% in EPA methods); (iii) no significant interference from either free available chlorine or chloramines at levels at or above their MRDLs; (iv) a sample analysis time of less than $30 \mathrm{~min}$; and (v) a simple method format that can be readily implemented by water treatment personnel.

This manuscript describes work to develop a single method that utilizes LGB and HRP to determine $\mathrm{ClO}_{2}{ }^{-}$and $\mathrm{ClO}_{2}$ concentrations in drinking water. This included the evaluation of the reaction between LGB and $\mathrm{ClO}_{2}$, and characterizing and optimizing the HRP-catalyzed conversion of $\mathrm{ClO}_{2}{ }^{-}$to $\mathrm{ClO}_{2}$ so that the reaction would proceed to completion in a reasonable time. This included evaluating the effect of $\mathrm{pH}, \mathrm{HRP}$ concentration, HRP activity, and temperature on the reaction rate. Finally, this paper describes the work to develop a common calibration procedure that did not require $\mathrm{ClO}_{2}$ standards, and the evaluation of method sensitivity, accuracy, and precision in finished waters. This work ultimately formed the basis for EPA Method 327.0 [22], which was recently approved for daily monitoring of $\mathrm{ClO}_{2}{ }^{-}$and $\mathrm{ClO}_{2}$ concentrations in drinking water from public water systems using $\mathrm{ClO}_{2}$ [23].

\section{Experimental}

\subsection{Reagents}

All chemicals were ACS grade unless otherwise noted. Types I, II and VI-A horseradish peroxidase were purchased from Sigma (St. Louis, MO) and had activities of 148, 158, and $288 \mathrm{U} \mathrm{mg}^{-1}$, respectively. Specified activity ranges were 15-150, 150-250, and 250-330 $\mathrm{U} \mathrm{mg}^{-1}$, respectively. Sigma defines the activity (U) as the amount of enzyme, which oxidizes $1 \mu \mathrm{M}$ of 2,2' -azino-bis(3-ethylbenzthiazoline-6-sulfonic acid) per minute at $\mathrm{pH} 6.0$ and $25^{\circ} \mathrm{C}$. According to Sigma, the Type I HRP is a crude product concentrated from extract of horseradish. The Type II product is further fractionated to remove some of the non-heme protein, and the Type VI-A product is further purified using ion chromatography [24]. Cost per analysis using the small volume technique at the optimized HRP concentration using the final Method 327 procedure is $\$ 0.23$, $\$ 0.39$ and \$3.02 for the Type I, II and VI-A HRP, respectively.

A chlorite ion standard $\left(1.00 \mathrm{mg} \mathrm{L}^{-1}\right)$ was purchased from Absolute Standards (Hamden, CT). Ammonium hydrogencitrate, trisodium citrate, sodium dihydrogen citrate sesquihydrate, glycine and chloroform were purchased from Sigma (St. Louis, MO, USA). Borate buffer was purchased from Fluka (St. Louis, MO). LGB (technical grade, 60\%), sodium chlorite and potassium persulfate were purchased from Aldrich (Milwaukee, WI). Deionized, organic free water, which is designated as reagent water in this manuscript, was obtained by using a Milli-Q Elix 3 reverse osmosis system with a Milli-Q Gradient A10 water purification system (Bedford, MA).

\subsection{Chlorine dioxide standard preparation}

$\mathrm{ClO}_{2}$ was generated by combining a solution containing $16 \mathrm{~g}$ sodium chlorite in $100 \mathrm{~mL}$ of reagent water with a solution of $8 \mathrm{~g}$ potassium persulfate in $200 \mathrm{~mL}$ of reagent water in a $500-\mathrm{mL}$ gas washing bottle (Ace Glass, Vineland, NJ) [25]. The reaction was allowed to proceed for 30 min while sparging nitrogen through the gas washing bottle at $250 \mathrm{~mL} \mathrm{~min}^{-1}$. The $\mathrm{ClO}_{2}$ was collected in a clear, 1-L bottle containing $500 \mathrm{~mL}$ of reagent water cooled with ice and protected from room light. The stock $\mathrm{ClO}_{2}$ solution was stored in headspace-free 6-mL amber vials with Teflon screw top caps at $4{ }^{\circ} \mathrm{C}$. Prior to use, each vial was equilibrated to room temperature and diluted 1:5 with reagent water to prepare the working standard with a concentration near $1.4 \mathrm{~g} \mathrm{~L}^{-1}$. This working standard was immediately transferred 
to a gastight syringe (either a 2.5 or a $5.0-\mathrm{mL}$ Hamilton, Reno, NV) and calibrated as described below.

A KD Scientific Model 100 syringe pump (Holliston, MA) equipped with a Hamilton gastight syringe was used to deliver the $\mathrm{ClO}_{2}$ working standard. A small Teflon tube (9 in. long) was attached to the syringe needle to allow accurate delivery of small aliquots. Because $\mathrm{ClO}_{2}$ is very volatile, standard delivery was accomplished by inserting the Teflon tube well below the surface of the sample being fortified. The concentration of the standard in each syringe was determined spectrophotometrically using a headspace-free technique and a $1-\mathrm{cm}$ pathlength quartz cell with a Teflon stopper. The $\mathrm{ClO}_{2}$ concentrations were calculated assuming a molar absorptivity coefficient for aqueous solutions of $\mathrm{ClO}_{2}$ at $360 \mathrm{~nm}$ of $1225 \mathrm{~cm}^{-1} \mathrm{M}^{-1}$ [25]. Each syringe was calibrated at the beginning, middle and end of the single-day experiments. Absorbance values for the $\mathrm{ClO}_{2}$ solutions typically varied less than $2 \%$ during an experimental day. Average concentrations were used for all calculations.

\subsection{Reagent preparation}

For the initial $\mathrm{ClO}_{2}$ studies, LGB stock solutions were prepared by dissolving $240 \mathrm{mg}$ in $250 \mathrm{~mL}$ of reagent water and allowing the solution to stir for $24 \mathrm{~h}$. Working stock solutions of LGB were prepared in a manner such that when diluted (as discussed below), they yielded an initial absorbance near 1.0. All HRP studies were conducted using a concentrated stock of $\mathrm{HRP}$ in reagent water that was stored at or below $6{ }^{\circ} \mathrm{C}$. For the LGB/HRP combined reagent studies, a concentrated citric acid/glycine buffer was prepared by mixing $9 \mathrm{~g}$ of trisodium citrate, $5 \mathrm{~g}$ sodium dihydrogen citrate, and $1 \mathrm{~g}$ glycine in $127 \mathrm{~mL}$ of reagent water. A buffered HRP solution was prepared by combining $240 \mathrm{mg}$ of the Type II HRP and $12.2 \mathrm{~mL}$ of the concentrated citric acid/glycine buffer in a $200-\mathrm{mL}$ volumetric flask and bringing it to volume with reagent water. An $80-\mathrm{mL}$ aliquot of the LGB stock solution was added to $12.2 \mathrm{~mL}$ of the concentrated citric acid/glycine buffer and brought to volume with reagent water in a $200-\mathrm{mL}$ volumetric flask to prepare a buffered LGB solution. The two buffered solutions were combined and stored in a 500-mL amber glass bottle with a Teflon screw cap. A $200-\mu \mathrm{L}$ aliquot of chloroform was added as a biocide. This LGB/HRP combined reagent, which had a final $\mathrm{pH}$ of 6.0, was shaken well and allowed to stand for at least $1 \mathrm{~h}$ prior to use. The combined LGB/HRP reagent was prepared fresh every two weeks.

\subsection{Large bottle $\mathrm{ClO}_{2}$ procedure}

A headspace-free procedure was developed for the initial $\mathrm{ClO}_{2}$ studies that employed tared, $125-\mathrm{mL}$ amber bottles with Teflon screw caps. Buffer was first added to each bottle (either $63 \mathrm{mg}$ of $\mathrm{pH} 8$ Tris preset crystals or an equivalent amount of the other buffers), and each bottle was filled to volume with reagent water. A calibration curve was prepared by delivering an aliquot of the working $\mathrm{ClO}_{2}$ standard $(60,180,300,420$, or $600 \mu \mathrm{L})$ deep into each bottle using the syringe pump. The bottles were quickly sealed and thoroughly mixed by inverting. A $10-\mathrm{mL}$ aliquot of the solution was withdrawn from the sample bottle using pipette, and a 10-mL aliquot of the LGB stock was added to yield an initial absorbance near one. Solutions were capped, and mixed again, and inverted to confirm they were free of air bubbles. Any bottle that contained headspace was rejected. A blank was prepared in an identical manner but did not contain $\mathrm{ClO}_{2}$. Precision and accuracy data were obtained by processing samples (or fortified reagent waters) in an identical manner to standards.

The blank and calibration standards were analyzed sequentially in a 1-cm cell using an Agilent (Model 8453) diode array spectrophotometer. The absorbance value was determined for each standard and blank and a calibration curve was established by plotting the absorbance difference (blank-calibration standard) at $633 \mathrm{~nm}$ versus $\mathrm{ClO}_{2}$ concentration. A liner regression that was not forced through zero was used to fit the data. Sample concentrations were calculated by comparing the absorbance difference (blank-sample) to the calibration curve.

\subsection{Micro procedure for $\mathrm{ClO}_{2}^{-}\left(\right.$or $\left.\mathrm{ClO}_{2}\right)$}

A scaled-down, headspace-free procedure was used for the HRP experiments. A set of about forty 16-mL amber glass vials were hand selected by gravimetric determination of their volumes. Vials were chosen such that all vials in the set had volumes within $\pm 1 \%$ of the average volume of the set.

The 16-mL amber glass vials were completely filled with reagent water (or sample matrix) fortified with known $\mathrm{ClO}_{2}{ }^{-}$ concentrations. A 1-mL aliquot was removed from each vial and replaced with a 1-mL aliquot of the citric acid/glycine buffer. Vials were capped and shaken and a second 1-mL aliquot was removed from each vial and replaced with a $1-\mathrm{mL}$ aliquot of the LGB/HRP combined reagent. Vials were capped, shaken and allowed to react for 20-30 min. A blank was prepared in an identical manner without the addition of $\mathrm{ClO}_{2}{ }^{-}$. Absorbance differences between the blank and calibration standards (or samples) were measured at $633 \mathrm{~nm}$ in a $1-\mathrm{cm}$ cell.

\subsection{Final method evaluation conditions}

The final method protocol is described in detail elsewhere [22]. It uses the micro procedure described above, but contains a combined HRP/LGB reagent, which was necessary to yield a single calibration curve as discussed below. A single procedural calibration curve is determined for $\mathrm{ClO}_{2}{ }^{-}$, which is used to calculate the concentration of both analytes. Samples are first measured to determine a total concentration of both species, and then a second, sparged sample is measured to determine the $\mathrm{ClO}_{2}{ }^{-}$concentration. The $\mathrm{ClO}_{2}$ concentration is calculated as the difference between the total and $\mathrm{ClO}_{2}{ }^{-}$concentrations.

\subsection{Temperature studies}

The effect of temperature on the reaction of HRP with chlorite ion was investigated by equipping the Agilent spectrophotometer with a Peltier (Model 89090A) thermostated cell holder. Prior to collecting data, an external temperature probe (HP Betather- 
mastat) was used to confirm that the contents of the cells reached the desired temperature. Experiments were conducted at 15, $25,35,45$, and $55^{\circ} \mathrm{C}$, using a Type I HRP concentration of $0.28 \mathrm{mg} \mathrm{mL}^{-1}$ and a $\mathrm{ClO}_{2}{ }^{-}$concentration of $1 \mathrm{mg} \mathrm{L}^{-1}$. In the experiments, all reagents except the HRP were allowed to equilibrate for $10 \mathrm{~min}$ in the thermostated cell holder prior to addition of the HRP, which was added $(63 \mu \mathrm{L}$ to $2.5 \mathrm{~mL}$ in the cell) at time zero.

\section{Results and discussion}

\subsection{Preliminary assessment of $L G B$ detection of $\mathrm{ClO}_{2}$}

LGB is a triphenylmethane dye with a high standard redox potential $(1.0 \mathrm{~V})[7]$ making it less subject to interferences from combined chlorine or chlorite ion. LGB has a $\mathrm{pH}$-dependent absorption maximum in the red region of the visible spectrum. For example, in Tris buffer the absorbance maxima were 615, 622 and $631 \mathrm{~nm}$ at $\mathrm{pH} \mathrm{9,8}$ and 7, respectively. The original evaluation of LGB was conducted at $\mathrm{pH} 9.0$ using an ammonium chloride/ammonia buffer [7]. The reason for using this $\mathrm{pH}$ value is that at $\mathrm{pH}$ 9, hypochlorite ion is the predominant FAC species, and it is a less powerful oxidant than hypochlorous acid. In addition, ammonia binds FAC to form chloramines, which are even weaker oxidants than hypochlorite ion [7]. A number of alternate reagents to remove FAC have been studied since this original work, allowing the investigation of alternate $\mathrm{pH}$ values. Eliminating the potential FAC interference was a key consideration since many drinking water systems use FAC to maintain a disinfectant residual in the distribution system.

Several buffer systems, including ammonium chloride/ ammonia, borate, phosphate buffers at $\mathrm{pH} \mathrm{9,} \mathrm{and} \mathrm{Tris} \mathrm{buffer}$ at $\mathrm{pH} \mathrm{7,8}$ and 9 were examined. Buffered reagent water solutions were prepared containing initial FAC concentrations of $8 \mathrm{mg} \mathrm{L}^{-1}$, which is twice the MRDL allowed under the Stage 1 D/DBP Rule [3]. For the ammonium chloride/ammonia and Tris buffers, which sequester FAC, the predominant chlorine species in solution is combined chlorine. Each solution was fortified with LGB and monitored at their absorbance maximum over a 2-h period. At $\mathrm{pH} 9$, each of the buffer systems exhibited a $4 \%$ loss in LGB absorbance in the absence of FAC (or combined chlorine) with the exception of borate buffer, which exhibited a $20 \%$ loss over the 2 -h period. The $\mathrm{pH} 9$ phosphate buffer for- tified with FAC showed a 59\% decrease in LGB absorbance over the 2 -h period, but was stable ( $4 \%$ loss) when the FAC was sequestered by adding $200 \mathrm{mg} \mathrm{L}^{-1}$ of ammonium chloride prior to the addition of LGB. The ammonium chloride/ammonia buffer fortified with combined chlorine, exhibited a $6 \%$ loss over the same period ( $2 \%$ more than the blank control which contained LGB at the same concentration in the same buffer without any FAC). The absorbance of LGB in Tris buffer at $\mathrm{pH} 9$ and 7 in the presence of combined chlorine diminished by $4 \%$ and $1 \%$, respectively over the same 2 -h period, indicating that lower $\mathrm{pH}$ values could be considered and may even be preferred as lower $\mathrm{pH}$ seems to slow the degradation of LGB.

Precision, accuracy and method detection limit [25] were evaluated using the large bottle technique described above in several buffer systems. Method detection limits were calculated according to the procedure described by Glaser et al. [26]. These data are presented in Table 1 . All buffers performed acceptably with the exception of the borate buffer system presumably due to the excessive downward drift in LGB absorbance noted above. A preliminary assessment of method performance in a local surface and groundwater performed similarly.

\subsection{Method design considerations}

Aqueous chlorine dioxide standards require daily calibration, a syringe pump or alternate headspace-free delivery device with appropriate accuracy, and a high degree of skill in headspacefree manipulation of potentially toxic, volatile standards. These requirements were incompatible with EPA's original method objectives; therefore a calibration approach that is used in the indigo method $[27,28]$ for determining ozone concentrations in water, the sensitivity coefficient adjustment, was considered. This approach would, if feasible, simplify calibration. To use this approach, however, the reaction stoichiometry must be known.

The apparent molar absorptivity coefficients were determined for two commercially available sources of LGB based on triplicate measurements in $\mathrm{pH} 6.0$ citric acid buffer, where the term "apparent" is used to indicate that the calculated molar absorptivities are not corrected for dye purity. The LGB obtained from Acros and Aldrich, which had manufacturer's purity ratings of $51.4 \%$ and $74.8 \%$, respectively, yielded apparent molar absorptivities of 44,890 and 71,510 $\left(\mathrm{cm}^{-1} \mathrm{M}^{-1}\right)$ at their absorbance maxima $(634 \mathrm{~nm})$. By using the Beer Lam-

Table 1

Evaluation of the $\mathrm{ClO}_{2}$ procedure in various buffer systems over the $\mathrm{pH}$ range of $7-9$ using the large bottle technique and gaseous $\mathrm{ClO}$ calibration standards

\begin{tabular}{|c|c|c|c|c|c|c|c|}
\hline \multirow[t]{2}{*}{ Buffer system } & \multirow[t]{2}{*}{$\operatorname{MDL}\left(\mathrm{mg} \mathrm{L}^{-1}\right)$} & \multicolumn{2}{|c|}{ Low-level $^{\mathrm{a}}$} & \multicolumn{2}{|c|}{ Mid-level $^{\mathrm{a}}$} & \multicolumn{2}{|c|}{ High-level $^{\mathrm{a}}$} \\
\hline & & Rec. $(\%)$ & R.S.D. (\%) & Rec. $(\%)$ & R.S.D. (\%) & Rec. $(\%)$ & R.S.D. (\%) \\
\hline Ammonia/ $\mathrm{NH}_{4} \mathrm{Cl}$ buffer $\mathrm{pH} 9$ & 0.043 & 95 & 5.9 & 115 & 9.5 & 114 & 8.0 \\
\hline Borate buffer $\mathrm{pH} 9$ & 0.14 & 159 & 12 & 126 & 5.3 & 105 & 3.2 \\
\hline Tris buffer $\mathrm{pH} 9.0$ & 0.12 & 101 & 16 & 105 & 4.0 & 96 & 2.6 \\
\hline Tris buffer $\mathrm{pH} 8.5$ & 0.075 & 88 & 12 & 113 & 8.4 & 98 & 1.8 \\
\hline Tris buffer $\mathrm{pH} 8.0$ & 0.080 & 73 & 15 & 105 & 7.1 & 101 & 0.3 \\
\hline Tris buffer $\mathrm{pH} 7.5$ & 0.081 & 90 & 11 & 113 & 2.7 & 104 & 0.5 \\
\hline Tris buffer $\mathrm{pH} 7.0$ & 0.077 & 110 & 9.2 & 111 & 2.1 & 110 & 0.6 \\
\hline
\end{tabular}

${ }^{a}$ Fortification levels for the low-, mid- and high-levels were $0.24,0.7$ and $2.3 \mathrm{mg} \mathrm{L}^{-1}$, respectively. R.S.D. (\%), percent relative standard deviation. Rec. (\%), percent recovery. 


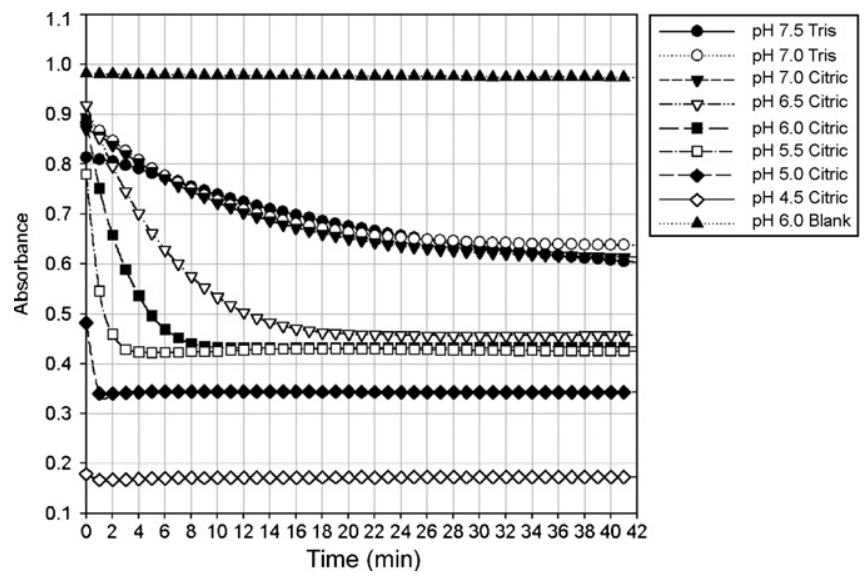

Fig. 1. The $\mathrm{pH}$ dependence of the $\mathrm{HRP}$ conversion of $\mathrm{ClO}_{2}{ }^{-}$to $\mathrm{ClO}_{2}$ measured by the disappearance of $\mathrm{LGB}$ with an initial $\mathrm{ClO}_{2}{ }^{-}$concentration of $1.0 \mathrm{mg} \mathrm{L}^{-1}$.

bert Law, this predicted an absorbance change of 1.1 for a $1.0 \mathrm{mg} \mathrm{L}^{-1}$ concentration of $\mathrm{ClO}_{2}$ assuming a 1:1 reaction stoichiometry. Because most of the calibration curves yielded slopes near $0.35\left(\Delta \mathrm{A} \mathrm{mg}{ }^{-1} \mathrm{~L}\right)$, the calculated reaction stoichiometry is not $1: 1$. This ruled out using the sensitivity coefficient adjustment approach $[27,28]$ and shifted focus on devising a calibration routine that employed the $\mathrm{HRP}$ conversion of $\mathrm{ClO}_{2}{ }^{-}$ to $\mathrm{ClO}_{2}$.

\subsection{The effect of $\mathrm{pH}$ on the Type I HRP reaction rate}

Original studies of the reaction rate for HRP-catalyzed conversion of $\mathrm{ClO}_{2}{ }^{-}$to $\mathrm{ClO}_{2}$ reported that the optimal $\mathrm{pH}$ was 4.1 [16]. Research conducted since then has indicated that disproportionation of $\mathrm{ClO}_{2}{ }^{-}$to form $\mathrm{ClO}_{2}[29,30]$ might contribute to the reported reaction rates at low $\mathrm{pH}$. Organic acids, like citric acid, have been shown to catalyze this reaction at even higher $\mathrm{pH}$ values [31]. This warranted studies to determine what effect, if any, disproportion plays in the conversion of $\mathrm{ClO}_{2}{ }^{-}$to $\mathrm{ClO}_{2}$.

A series of kinetic studies were conducted using Tris and citric acid buffer systems that spanned the $\mathrm{pH}$ range from 4.5 to 7.5. Tris has a single $\mathrm{p} K_{\mathrm{a}}$ at 8.07 and is not a suitable buffer below $\mathrm{pH}$ 7.0. Citric acid, with $\mathrm{p} K_{\mathrm{a}}$ values of $3.14,4.77$, and 6.39 , is a much better buffer in the $\mathrm{pH}$ range of 2-7. In each experiment, the initial $\mathrm{ClO}_{2}{ }^{-}$concentration was $1.0 \mathrm{mg} \mathrm{L}^{-1}(15 \mu \mathrm{M})$, the HRP concentration was $0.055 \mathrm{mg} \mathrm{mL}^{-1}(1.3 \mu \mathrm{M})$, and the LGB concentration was $14 \mu \mathrm{M}$ (using the apparent molar absorptivity coefficient reported above). As indicated in Fig. 1, the reaction rate exhibited a dramatic dependence on $\mathrm{pH}$, as did the apparent stoichiometry of the reaction, which is currently not understood. An experiment conducted similar to the $\mathrm{pH} 4.5$ experiment but without HRP showed no noticeable decrease in LGB absorbance and ruled out any contribution from disproportionation over the $\mathrm{pH}$ range studies. The behavior shown in Fig. 1, clearly illustrates the important role that buffer $\mathrm{pH}$ plays in method performance. Based on these data, the $\mathrm{pH} 6$ citric acid buffer was chosen for two reasons: the absorbance change with time (or method sensitivity) was not affected by small

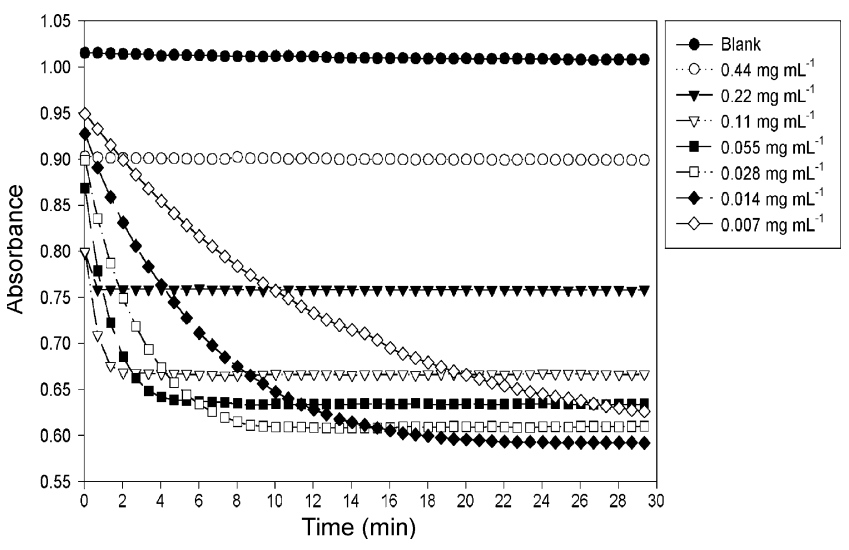

Fig. 2. Reaction rate in $\mathrm{pH} 6.0$ citrate buffer as a function of HRP concentration for a chlorite concentration of $1.0 \mathrm{mg} \mathrm{L}^{-1}$.

changes in $\mathrm{pH}$; and the reaction required less than $30 \mathrm{~min}$ for completion.

\subsection{Optimization of Type I HRP concentration}

Hewson and Hager [18] reported that lower concentrations of $\mathrm{HRP}$ are more efficient at producing $\mathrm{ClO}_{2}$, e.g., more moles of $\mathrm{ClO}_{2}$ are produced per mole of $\mathrm{HRP}$, and for a constant concentration of HRP, higher concentrations of $\mathrm{ClO}_{2}{ }^{-}$also formed more $\mathrm{ClO}_{2}$. This warranted an investigation of reaction rates over the $\mathrm{ClO}_{2}{ }^{-}$concentration range of interest, which was initially established as $0.25-2.0 \mathrm{mg} \mathrm{L}^{-1}(3.7-30 \mu \mathrm{M})$. For these studies, Type I HRP obtained from Sigma-Aldrich was utilized. The relevance of enzyme "type" is discussed below. A series of 30-min kinetic experiments were conducted at seven HRP concentrations ranging from 0.44 to $0.0070 \mathrm{mg} \mathrm{L}^{-1}(10-0.16 \mu \mathrm{M})$ for four $\mathrm{ClO}_{2}{ }^{-}$concentrations $\left(0.25,0.50,1.0\right.$ and $\left.2.0 \mathrm{mg} \mathrm{L}^{-1}\right)$. All experiments were conducted at room temperature in $\mathrm{pH}$ 6.0 ammonium hydrogencitrate buffer using the small volume technique described above. The enzyme concentrations were specifically chosen to achieve a sufficiently fast reaction at all concentrations ultimately yielding reaction times of $20 \mathrm{~min}$ or less. The data from the mid-level $\mathrm{ClO}_{2}{ }^{-}$concentration experiments are presented in Fig. 2. The figures obtained at other $\mathrm{ClO}_{2}{ }^{-}$concentrations are available as supplemental information (Supplemental information, Figs. SI1-SI3).

The kinetic studies presented in Fig. 2 exhibited inhibition at high HRP concentrations, which was apparent in the $0.22 \mathrm{mg} \mathrm{mL}^{-1} \mathrm{HRP}$ experiment $(5.0 \mu \mathrm{M}$ HRP with $15 \mu \mathrm{M} \mathrm{ClO}_{2}{ }^{-}$) and increased at the higher HRP concentration. Inhibition was more evident in the lower $\mathrm{ClO}_{2}{ }^{-}$ concentration experiments. For example, the $0.25 \mathrm{mg} \mathrm{L}^{-1}$ $(3.7 \mu \mathrm{M}) \mathrm{ClO}_{2}{ }^{-}$solutions began to exhibit this phenomenon at $0.055 \mathrm{mg} \mathrm{mL}^{-1}(1.2 \mu \mathrm{M}) \mathrm{HRP}$ and total inhibition of $\mathrm{ClO}_{2}$ production was observed in the $\geq 0.22 \mathrm{mg} \mathrm{mL}^{-1}(5.0 \mu \mathrm{M}) \mathrm{HRP}$ concentration experiments. Only the highest HRP concentration $\left(0.44 \mathrm{mg} \mathrm{mL}^{-1}\right.$ or $\left.10 \mu \mathrm{M}\right)$ showed any inhibition in the $2.0 \mathrm{mg} \mathrm{L}^{-1}(30 \mu \mathrm{M}) \mathrm{ClO}_{2}{ }^{-}$concentration experiments. In all of these experiments, the initial LGB absorbance was near 1 , which equates to an initial LGB concentration of about $14 \mu \mathrm{M}$. 


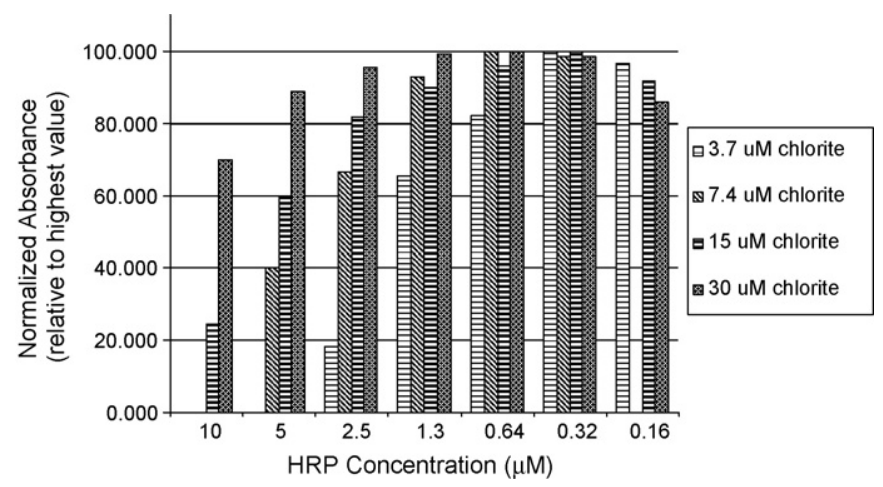

Fig. 3. Absorbance change as a function of HRP concentration normalized at each $\mathrm{ClO}_{2}{ }^{-}$concentration.

This inhibition was also investigated as a function of enzyme activity. These data are reported in the section below.

Hewson and Hager [18] suggested that $\mathrm{ClO}_{2}$ could react with the HRP and at high enough $\mathrm{ClO}_{2}$ concentrations this reaction could inactivate the enzyme. To investigate this further, an experiment was conducted in triplicate in which $\mathrm{ClO}_{2}{ }^{-}$ $1.0 \mathrm{mg} \mathrm{L}^{-1}(15 \mu \mathrm{M})$ and HRP $0.028 \mathrm{mg} \mathrm{mL}^{-1}(0.64 \mu \mathrm{M})$ were allowed to react in a headspace-free container for $20 \mathrm{~min}$ prior to the addition of LGB. In each case, the absorbance of the solution was not different from the blank indicating that the $\mathrm{ClO}_{2}$ had been consumed by an alternate or competing reaction.

Although inhibition details remain unclear, the HRP concentration affects the rate and amount of LGB consumed by $\mathrm{ClO}_{2}$. HRP concentration optimization studies (Fig. 3) were done by normalizing all data relative to the largest absorbance change (blank-sample). With the exception of the data set at the $\mathrm{ClO}_{2}{ }^{-}$and HRP concentrations of $0.50 \mathrm{mg} \mathrm{L}^{-1}(7.4 \mu \mathrm{M})$ and $0.0070 \mathrm{mg} \mathrm{mL}^{-1}(0.16 \mu \mathrm{M})$, which was unintentionally omitted in the experiment, all data sets without a histogram bar represent complete inhibition (no change in LGB absorbance). The optimum Type I HRP concentration was $0.028 \mathrm{mg} \mathrm{mL}^{-1}$ $(0.64 \mu \mathrm{M})$. Measurements at this concentration exhibited a relative absorbance near $100 \%$ for all concentrations. Furthermore, the reactions at $0.028 \mathrm{mg} \mathrm{mL}^{-1}$ were completed faster than those using $0.014 \mathrm{mg} \mathrm{mL}^{-1} \mathrm{HRP}$.

\subsection{Evaluation of enzyme type}

Numerous types of HRP enzyme are available. Experiments described above were conducted exclusively with Type I HRP. As indicated in Section 2.1, the lot of Type I enzyme available for these studies was at the top of the specified activity range (148 $\mathrm{U} \mathrm{mg}^{-1}$, range $\left.15-150 \mathrm{U} \mathrm{mg}^{-1}\right)$. This warranted the evaluation of additional types of HRP. This included the evaluation of a Type II material that was near its lower limit of activity and a Type VI-A HRP with average activity. Kinetic studies were conducted at room temperature using Type II and Type VI-A HRP in a manner identical to the experiments described above for the Type I enzyme at a $\mathrm{ClO}_{2}{ }^{-}$concentration of $1.0 \mathrm{mg} \mathrm{L}^{-1}$ (Supplemental information, Figs. SI4 and SI5). The reactions with the Type VI-A and II HRP were faster than the Type I enzyme. This was most pronounced at low enzyme concentration. In addition, both Type II and VI-A showed less susceptibility towards inhibition at high HRP concentration. The Type I enzyme showed inhibition at the two highest HRP concentrations evaluated, the Type II HRP at only the highest HRP concentration, and the Type VI-A HRP did not exhibit inhibition at any concentration. These data seem to indicate that the competing reaction that results in diminished degradation of LGB is not an intramolecular reaction (with respect to HRP). It is possible that an impurity, removed during HRP refinement, reacts preferentially with $\mathrm{ClO}_{2}$. Ruling out such an occurrence would not be a trivial task.

The Type VI-A HRP has the highest reaction rate and as a result is least subject to inhibition; however, the increase in cost is significant (see Section 2.1). Since the Type I enzyme evaluated in these studies was very near the upper purity limit of the manufacturer's specification, the Type II enzyme which added only modest cost was the obvious choice for the method. In addition, because the Type I enzyme was essentially at the lower activity limit for the Type II HRP, the concentration optimized in the above section was not altered.

\subsection{Effect of temperature on HRP reaction rate}

Temperature is widely understood to affect enzyme turnover rates, which could adversely affect method robustness and precision. To address this concern, the effect of temperature on enzyme kinetics was investigated for the Type I HRP. The activity of the Type I enzyme was very near the lower range limit of the Type II HRP. Experiments were conducted at 15, $25,35,45$, and $55^{\circ} \mathrm{C}$ using the optimum HRP concentration of $0.028 \mathrm{mg} \mathrm{mL}^{-1}$ and $\mathrm{a} \mathrm{ClO}_{2}^{-}$concentration of $1.0 \mathrm{mg} \mathrm{L}^{-1}$, respectively (Supplemental information, Fig. SI6). The rate of $\mathrm{ClO}_{2}$ generation (or LGB consumption) increased with increasing temperature, but the rate increases were smaller than expected. At $55^{\circ} \mathrm{C}$, the reaction was complete in about $10 \mathrm{~min}$, while the $15^{\circ} \mathrm{C}$ experiment required $17 \mathrm{~min}$ - both acceptable reaction times. Reaction rates at other temperatures fell between these two values. Based on these results, it was determined that the effect of temperature on this reaction was negligible over the range of temperatures that will likely be encountered in the laboratory environment.

\subsection{Initial assessment of chlorite ion method performance}

An initial assessment was conducted on the $\mathrm{ClO}_{2}^{-}$portion of the method using the micro procedure that had been optimized using pH 6 citric acid/glycine buffer. Method detection limits were determined according to Glaser et al. [26] in reagent water, a chlorinated surface water, and $\mathrm{ClO}_{2}$-treated groundwater. These were $0.063,0.045$ and $0.12 \mathrm{mg} \mathrm{L}^{-1}$, respectively, for each matrix fortified with $\mathrm{ClO}_{2}{ }^{-}$at a concentration of $0.50 \mathrm{mg} \mathrm{L}^{-1}$. The groundwater was sparged for $10 \mathrm{~min}$ to remove any residual $\mathrm{ClO}_{2}$ prior to fortification with $\mathrm{ClO}_{2}{ }^{-}$. Precision and accuracy in these matrices were also assessed and are reported in Table 2 . Method performance was adequate in all matrices. 
Table 2

Accuracy and precision for the micro procedure using HRP for the determination of chlorite reagent water and two finished tap waters

\begin{tabular}{|c|c|c|c|c|c|c|c|c|c|}
\hline \multirow[t]{2}{*}{ Matrix } & \multicolumn{3}{|l|}{ Low-level } & \multicolumn{3}{|l|}{ Mid-level } & \multicolumn{3}{|l|}{ High-level } \\
\hline & $\begin{array}{l}\text { Spike level } \\
\left(\mathrm{mg} \mathrm{L}^{-1}\right)\end{array}$ & Mean Rec. (\%) & $\begin{array}{l}\text { R.S.D. } \\
(\%)\end{array}$ & $\begin{array}{l}\text { Spike level } \\
\left(\mathrm{mg} \mathrm{L}^{-1}\right)\end{array}$ & Mean Rec. (\%) & R.S.D. ${ }^{\mathrm{a}}(\%)$ & $\begin{array}{l}\text { Spike level } \\
\left(\mathrm{mg} \mathrm{L}^{-1}\right)\end{array}$ & Mean Rec. (\%) & R.S.D. ${ }^{\mathrm{a}}(\%)$ \\
\hline $\mathrm{RW}^{\mathrm{b}}$ & 0.50 & 97.6 & 4.1 & 1.0 & 109 & 1.9 & 2.0 & 98 & 0.5 \\
\hline $\mathrm{SW}^{\mathrm{c}}$ & 0.50 & 85 & 6.7 & 1.0 & 103 & 1.4 & 2.0 & 97 & 1.3 \\
\hline $\mathrm{GW}^{\mathrm{d}}$ & 0.50 & 81 & 9.5 & 1.0 & 104 & 0.8 & 2.0 & 97 & 0.6 \\
\hline
\end{tabular}

a R.S.D., percent relative standard deviation.

b RW, reagent water.

c Finished surface water from a municipality disinfected with chlorine.

d Groundwater from a municipality disinfected with chlorine with a hardness $>300 \mathrm{mg} \mathrm{L}^{-1}\left(\mathrm{CaCO}_{3}\right)$.

\subsection{Developing a common calibration technique for $\mathrm{ClO}_{2}$ and $\mathrm{ClO}_{2}{ }^{-}$}

The technical challenges associated with the headspace-free manipulation of $\mathrm{ClO}_{2}$ standards together with its caustic nature ruled out calibration using aqueous $\mathrm{ClO}_{2}$ standards. The stoichiometry of the reaction between $\mathrm{ClO}_{2}$ and LGB was not one-to-one, a necessity for sensitivity coefficient adjustment. This meant external calibration was required for $\mathrm{ClO}_{2}$ and $\mathrm{ClO}_{2}{ }^{-}$. However, data collected during the initial evaluation of LGB for the detection of $\mathrm{ClO}_{2}$ and $\mathrm{ClO}_{2}{ }^{-}$seemed to indicate that the slopes for each analyte differed, and that the slope of the calibration curves might be dependent on the concentration of LGB.

The initial concentration of LGB was varied to provide an absorbance range from approximately $1.0-3.5$ in a $1-\mathrm{cm}$ cell. Actual absorbance measurements were all made using a 5-mm pathlength cell in an attempt to remain within the linear region of the spectrophotometer. Experiments were conducted at $\mathrm{pH} 6$ using the citric acid/glycine buffer, with a relatively high concentration of both $\mathrm{ClO}_{2}$ and $\mathrm{ClO}_{2}^{-}$(e.g., $1.7 \mathrm{mg} \mathrm{L}^{-1}$ ). The $\mathrm{ClO}_{2}{ }^{-}$ experiments contained Type II HRP at $0.028 \mathrm{mg} \mathrm{mL}^{-1}$; the $\mathrm{ClO}_{2}$ experiments did not (Supplemental information, Fig. SI7). Both reactions exhibited a sensitivity ( $\triangle \mathrm{A}$ per $\mathrm{mg} \mathrm{L}^{-1}$ of analyte) that was dependent on LGB concentration, and at all LGB concentrations the sensitivity for $\mathrm{ClO}_{2}{ }^{-}$was higher than $\mathrm{ClO}_{2}$. This is surprising, since the detection of $\mathrm{ClO}_{2}{ }^{-}$first requires its HRPcatalyzed conversion to $\mathrm{ClO}_{2}$, and this reaction was not expected to be $100 \%$ efficient.

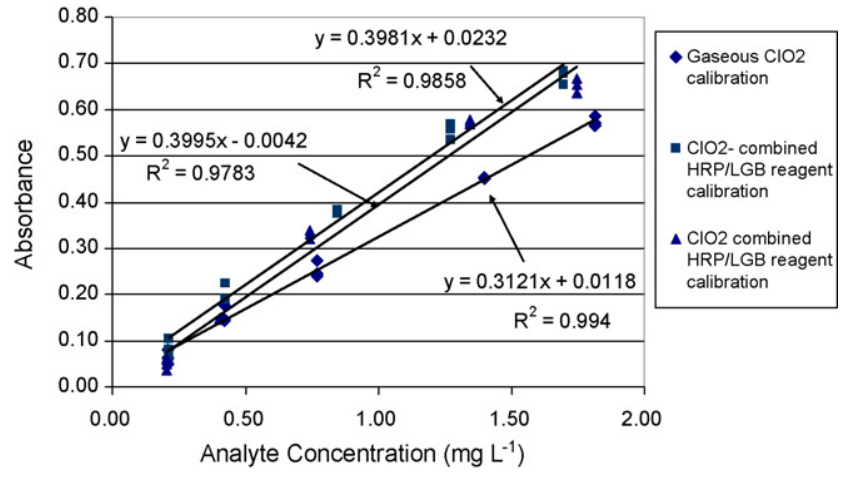

Fig. 4. Slopes of calibration curves recorded for $\mathrm{ClO}_{2}$ with gaseous $\mathrm{ClO}_{2}$ calibration, and $\mathrm{ClO}_{2}{ }^{-}$and $\mathrm{ClO}_{2}$ using the combined HRP/LGB reagent.

Perhaps HRP plays a role in increasing the sensitivity by reacting with impurities in the LGB that would otherwise react with chlorine dioxide. To investigate this further, the micro procedure and a combined LGB/HRP reagent were used to generate calibration curves for $\mathrm{ClO}_{2}^{-}$and $\mathrm{ClO}_{2}$ over a concentration range of 0.25 to $1.8 \mathrm{mg} \mathrm{L}^{-1}$. These curves were compared to a third prepared for $\mathrm{ClO}_{2}$ with LGB but without the HRP (Fig. 4). The micro technique using the combined reagent yielded slopes for both analytes that were in good agreement.

\subsection{Evaluation of final method performance}

The combined reagent was further optimized to yield a linear dynamic range of 0.25 to $2.3 \mathrm{mg} \mathrm{L}^{-1} \mathrm{ClO}_{2}{ }^{-}$for evaluation

Table 3

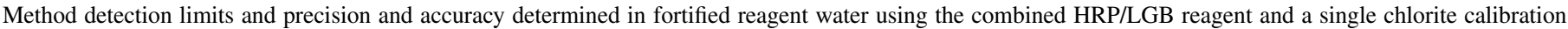
curve according to the final Method 327.0 procedure

\begin{tabular}{|c|c|c|c|c|c|c|c|}
\hline \multicolumn{2}{|c|}{ Fortification concentration } & \multicolumn{3}{|l|}{ Chlorite } & \multicolumn{3}{|c|}{ Chlorine dioxide } \\
\hline $\mathrm{ClO}_{2}^{-}\left(\mathrm{mg} \mathrm{L}^{-1}\right)$ & $\mathrm{ClO}_{2}\left(\mathrm{mg} \mathrm{L}^{-1}\right)$ & Recovery (\%) & R.S.D. (\%) & $\operatorname{MDL}\left(\mathrm{mg} \mathrm{L}^{-1}\right)$ & Recovery (\%) & R.S.D. (\%) & $\operatorname{MDL}\left(\mathrm{mg} \mathrm{L}^{-1}\right)$ \\
\hline 0.25 & SNF & 112 & 12 & 0.11 & SNF & SNF & SNF \\
\hline 0.25 & 0.95 & 118 & 8.5 & 0.078 & 116 & 3.6 & $\mathrm{NC}$ \\
\hline SNF & 0.26 & SNF & SNF & $\mathrm{SNF}$ & 102 & 5.1 & 0.042 \\
\hline 1.0 & 0.26 & 103 & 2.9 & $\mathrm{NC}$ & 124 & 16 & 0.16 \\
\hline 1.0 & 0.94 & 98.5 & 3.2 & $\mathrm{NC}$ & 111 & 4.8 & $\mathrm{NC}$ \\
\hline
\end{tabular}

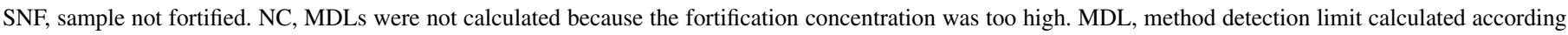
to [26]. 
Table 4

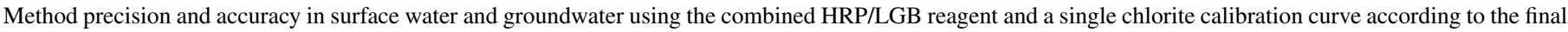
Method 327.0 procedure

\begin{tabular}{|c|c|c|c|c|c|}
\hline \multicolumn{2}{|l|}{ Fortification level } & \multicolumn{2}{|l|}{ Chlorite } & \multicolumn{2}{|c|}{ Chlorine dioxide } \\
\hline $\mathrm{ClO}_{2}^{-}\left(\mathrm{mg} \mathrm{L}^{-1}\right)$ & $\mathrm{ClO}_{2}\left(\mathrm{mg} \mathrm{L}^{-1}\right)$ & Recovery (\%) & R.S.D. (\%) & Recovery (\%) & R.S.D. (\%) \\
\hline \multicolumn{6}{|l|}{ Surface water ${ }^{\mathrm{a}}$} \\
\hline 1.0 & SNF & 107 & 4.2 & SNF & SNF \\
\hline SNF & 0.82 & SNF & SNF & 100 & 1.9 \\
\hline 1.0 & 0.82 & 109 & 3.7 & 91.3 & 8.9 \\
\hline 2.0 & SNF & 105 & 1.4 & SNF & SNF \\
\hline $\mathrm{SNF}$ & 1.94 & $\mathrm{SNF}$ & $\mathrm{SNF}$ & 96.9 & 1.0 \\
\hline \multicolumn{6}{|l|}{ Groundwater $^{b}$} \\
\hline 1.0 & SNF & 110 & 4.4 & SNF & SNF \\
\hline SNF & 0.90 & SNF & SNF & 92.0 & 3.3 \\
\hline 1.0 & 0.90 & 107 & 1.6 & 93.8 & 3.0 \\
\hline 2.0 & $\mathrm{SNF}$ & 100 & 2.7 & SNF & SNF \\
\hline SNF & 2.0 & SNF & SNF & 110 & 1.7 \\
\hline
\end{tabular}

${ }^{\text {a }}$ Finished surface water contained $0.9 \mathrm{mg} \mathrm{L}^{-1}$ FAC.

b Finished groundwater contained $0.8 \mathrm{mg} \mathrm{L}^{-1} \mathrm{FAC}$ and had a hardness of $325 \mathrm{mg} \mathrm{L}^{-1}\left(\mathrm{CaCO}_{3}\right)$. SNF, sample not fortified.

in the final method. The resulting method [22] is a method by difference, which first analyzes total $\mathrm{ClO}_{2}{ }^{-}$and $\mathrm{ClO}_{2}$, and then determines the $\mathrm{ClO}_{2}{ }^{-}$concentration in a second, sparged sample. $\mathrm{ClO}_{2}$ concentrations are then calculated by difference. Studies were designed to determine MDLs, accuracy and precision in reagent water in a manner that would pose a reasonable challenge to the method. For example, MDLs were determined for reagent waters containing single analytes and for reagents with one analyte at the lowest calibration concentration and the other at its regulatory limit, the MRDL or the MCL as reported above. These data, reported in Table 3, demonstrated acceptable method performance. Studies were next designed to evaluate method precision and accuracy in a finished groundwater and surface water. These studies were designed to assess single analyte performance near the regulatory limit and near the upper limit of the calibration range and to assess method performance with both analytes near their regulatory limits. These data (Table 4) also met method performance objectives.

\section{Conclusions}

LGB was selected for the analysis of $\mathrm{ClO}_{2}$ in finished drinking water because it had fewer interferences and better sensitivity than other approaches. While investigating LGB, several properties were uncovered that posed significant challenges requiring the use of an alternate calibration procedure. The HRP-catalyzed conversion of $\mathrm{ClO}_{2}{ }^{-}$into $\mathrm{ClO}_{2}$ was selected as a potential answer.

Kinetics studies showed that the HRP conversion of $\mathrm{ClO}_{2}{ }^{-}$ to $\mathrm{ClO}_{2}$ accelerated as $\mathrm{pH}$ was decreased, and that disproportionation did not contribute to the formation of $\mathrm{ClO}_{2}$ even at the lowest $\mathrm{pH}$ studied. The enzyme concentration was optimized to avoid a competing reaction that consumes $\mathrm{ClO}_{2}$ at high $\mathrm{HRP}$ concentrations while achieving a suitable reaction analysis time at a reasonable cost. The competing reaction was less prominent and/or absent for the more purified forms of HRP. The mechanism of this inhibition reaction is currently not understood.
The slope of the calibration curves were larger for the HRPgenerated $\mathrm{ClO}_{2}$ than for $\mathrm{ClO}_{2}$ added directly into solution. This required the use of a combined HRP/LGB reagent and the use of an identical reaction time for both $\mathrm{ClO}_{2}$ and $\mathrm{ClO}_{2}{ }^{-}$. The latter was required because the oxidation of $\mathrm{LGB}$ by $\mathrm{ClO}_{2}$ in the presence of HRP exhibited both a fast and a slow reaction with a kinetic profile similar to that of the HRP-catalyzed reaction that contributed to sensitivity.

The performance of the final method was evaluated in reagent water and in finished waters fortified with $\mathrm{ClO}_{2}$ and $\mathrm{ClO}_{2}{ }^{-}$. Method detection limit, linearity and sensitivity (or slope), accuracy, precision and robustness met the original project objectives and warranted publication as EPA Method 327.0. Future studies could include investigation of reagent stability, and a full characterization of potential method interferences.

\section{Acknowledgements}

Work was supported on-site at EPA's Technical Support Center laboratory located in Cincinnati, Ohio. This work has been funded wholly or in part by the United States Environmental Protection Agency under an on-site contract (Contract Number: 68-C-01-098) to Shaw Environmental, Inc. This paper has been subject to the Agency's review, and it has been approved for publication as an EPA document. Mention of trade names or commercial products does not constitute endorsement or recommendation for use. The authors would like to acknowledge members of the American Chemical Society Chlorine Dioxide Panel for introducing the concept of using HPR to convert chlorite to chlorine dioxide to EPA as well as Dr. Bernard Bubnis, who worked with EPA to demonstrate the initial proof of concept.

\section{Appendix A. Supplementary data}

Supplementary data associated with this article can be found, in the online version, at doi:10.1016/j.aca.2007.06.006. 


\section{References}

[1] Environmental Protection Agency, Alternative disinfectants and oxidants guidance manual, April 1999, Office of Water, EPA 815-R-99-014.

[2] Environmental Protection Agency, Health risk assessment/characterization of the drinking water disinfection byproduct chlorine dioxide and the degradation byproduct chlorite, Office of Science and Technology, Office of Water, October 15, 1998, EPA 815-B-98-008, PB 99-111361.

[3] Environmental Protection Agency, Fed. Reg. 1998, 63 (241) 69390-69476.

[4] Standard Method 4500- $\mathrm{ClO}_{2}$ D. DPD Method, in: A.D. Eaton, L.S. Clesceri, A.E. Greenburg, M.A.H. Franson (Eds.), Standard Methods for the Examination of Water and Wastewater, nineteenth ed., American Public Health Association, Washington, DC, 1995.

[5] G. Gordon, W.J. Cooper, R.G. Rice, G.E. Pacey, Disinfectant Residual Measurement Methods, second ed., Am. Waterworks Assoc. Res. Found., Denver, CO, 1992.

[6] Standard Method 4500- $\mathrm{ClO}_{2}$ E. Amperometric Method II, in: A.D. Eaton, L.S. Clesceri, A.E. Greenburg, M.A.H. Franson (Eds.), Standard Methods for the Examination of Water and Wastewater, nineteenth ed., American Public Health Association, Washington, DC, 1995.

[7] B. Chiswell, K.R. O'Halloran, Analyst 116 (1991) 657.

[8] W.J. Masschelein, Anal. Chem. 38 (13) (1996) 1839.

[9] W.J. Masschelein, G. Fransolet, P. Laforge, R. Savoir, Ozone: Sci. Eng. 11 (1989) 209.

[10] G.L. Emmert, D.E. Coutant, D.L. Sweetin, G. Gordon, B. Bubnis, Talanta 51 (2000) 879 .

[11] D.L. Harp, R.L. Klein, D.J. Schoonover, J. AWWA 73 (6) (1981) 387.

[12] I.J. Fletcher, P. Hemmings, Analyst 110 (1985) 695.

[13] D.L. Sweetin, E. Sullivan, G. Gordon, Talanta 43 (1996) 103.

[14] R. Hoffmann, Q. Ye, R.C. Andrews, Comparison of the ACVK and LGB methods for measuring chlorine dioxide in drinking water, in: Proceedings of the WQTC, Denver, CO, 1997.
[15] R. Hoffman, R.C. Andrews, Q. Ye, Environ. Technol. 19 (1998) 761.

[16] P.F. Hollenberg, T. Rand-Meir, L.P. Hager, J. Biol. Chem. 24 (1974) 5816.

[17] I. Wilson, K.R. Bretscher, C.K. Chea, H.C. Kelly, J. Inorg. Biochem. 19 (1983) 345

[18] W.D. Hewson, L.P. Hager, J. Biol. Chem. 254 (9) (1979) 3175.

[19] W.D. Hewson, L.P. Hager, J. Biol. Chem. 254 (9) (1979) 3182.

[20] S. Shahangian, L.P. Hager, J. Biol. Chem. 256 (12) (1981) 6034.

[21] H.C. Kelly, K.J. Parigi, I. Wilson, M. Davies, P. Jones, L. Roettger, J. Inorg. Chem. 20 (1981) 1086.

[22] Environmental Protection Agency, Method 327.0-Revision 1.1, Determination of chlorine dioxide and chlorite ion in drinking water using lissamine green $\mathrm{B}$ and horseradish peroxidase with detection by visible spectrophotometry, Office of Ground Water and Drinking Water, Cincinnati, OH, 2005 (EPA 815-R-05-008), http://www.epa.gov/safewater/methods/sourcalt.html.

[23] Environmental Protection Agency, Fed. Reg., 71(2) (2006) 388-493.

[24] A. O'Connor, Sigma Technical Representative, Personal Communication, May 2002.

[25] R.D. Gauw, G.L. Emmert, B. Bubnis, G. Gordon, Talanta 50 (1999) 1073.

[26] J.A. Glaser, D.L. Foerst, G.D. McKee, S.A. Quave, W.L. Budde, Environ. Sci. Technol. 15 (1981) 1426.

[27] G. Gordon, R.D. Gauw, Y. Miyahara, B. Walters, B. Bubnis, J. AWWA 92 (2000) 96.

[28] G. Gordon, B. Bubnis, Ozone: Sci. Eng. 24 (1) (2002) 17.

[29] R.G. Kieffer, G. Gordon, Inorg. Chem. 7 (1968) 235.

[30] R.G. Kieffer, G. Gordon, Inorg. Chem. 7 (1968) 239.

[31] L.F. Crawford, Novel methods for the generation of chlorine dioxide from sodium chlorite: the lactic acid system, Ph.D. thesis, Miami University, Oxford, OH, 1995. 
Figure SI1: Reaction rate in $\mathrm{pH} 6.0$ citrate buffer as a function of Type I HRP concentration for a chlorite concentration of $0.25 \mathrm{mg} \mathrm{L}^{-1}$.

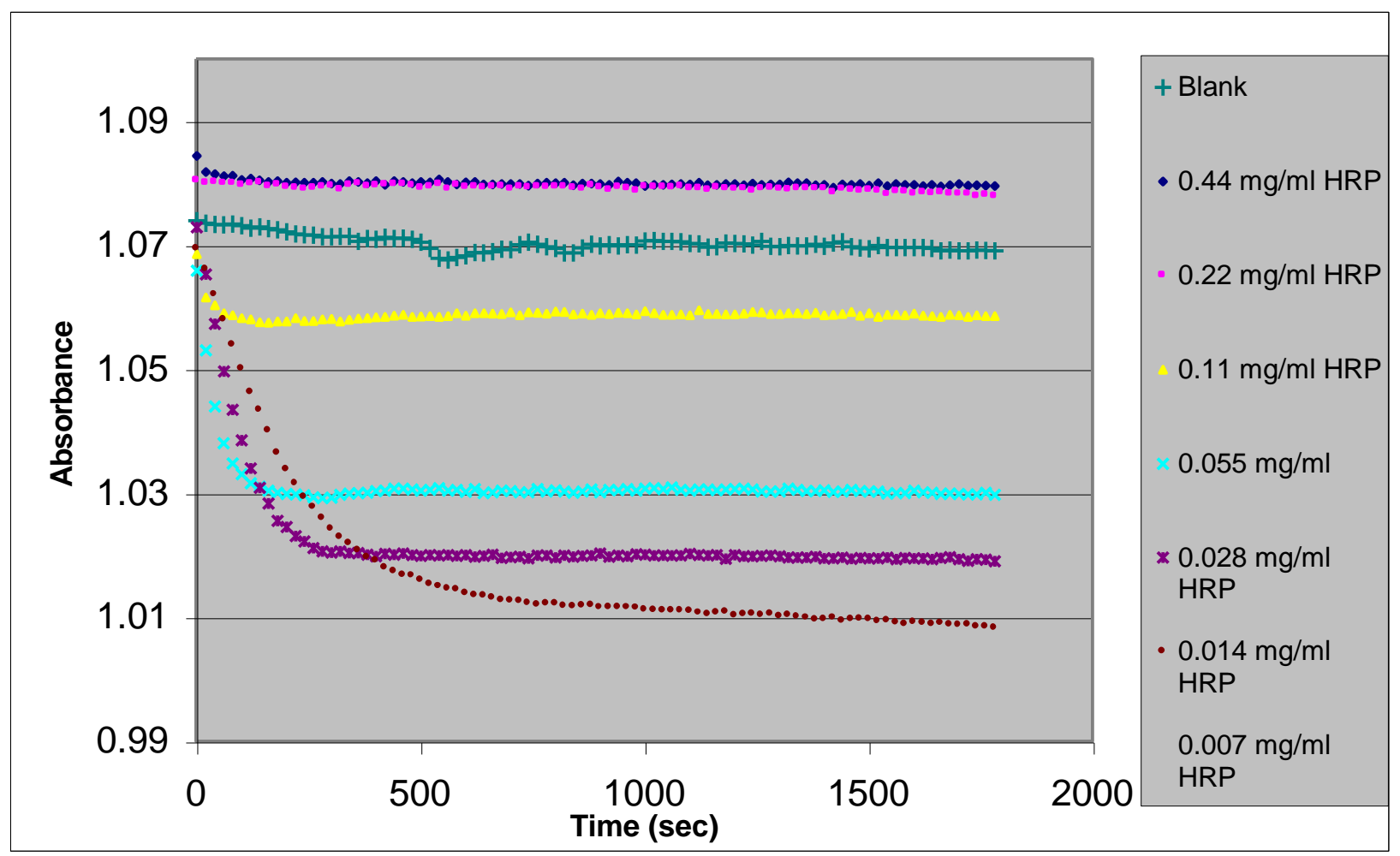


Figure SI2: Reaction rate in $\mathrm{pH} 6.0$ citrate buffer as a function of Type I HRP concentration for a chlorite concentration of $0.50 \mathrm{mg} \mathrm{L}^{-1}$.

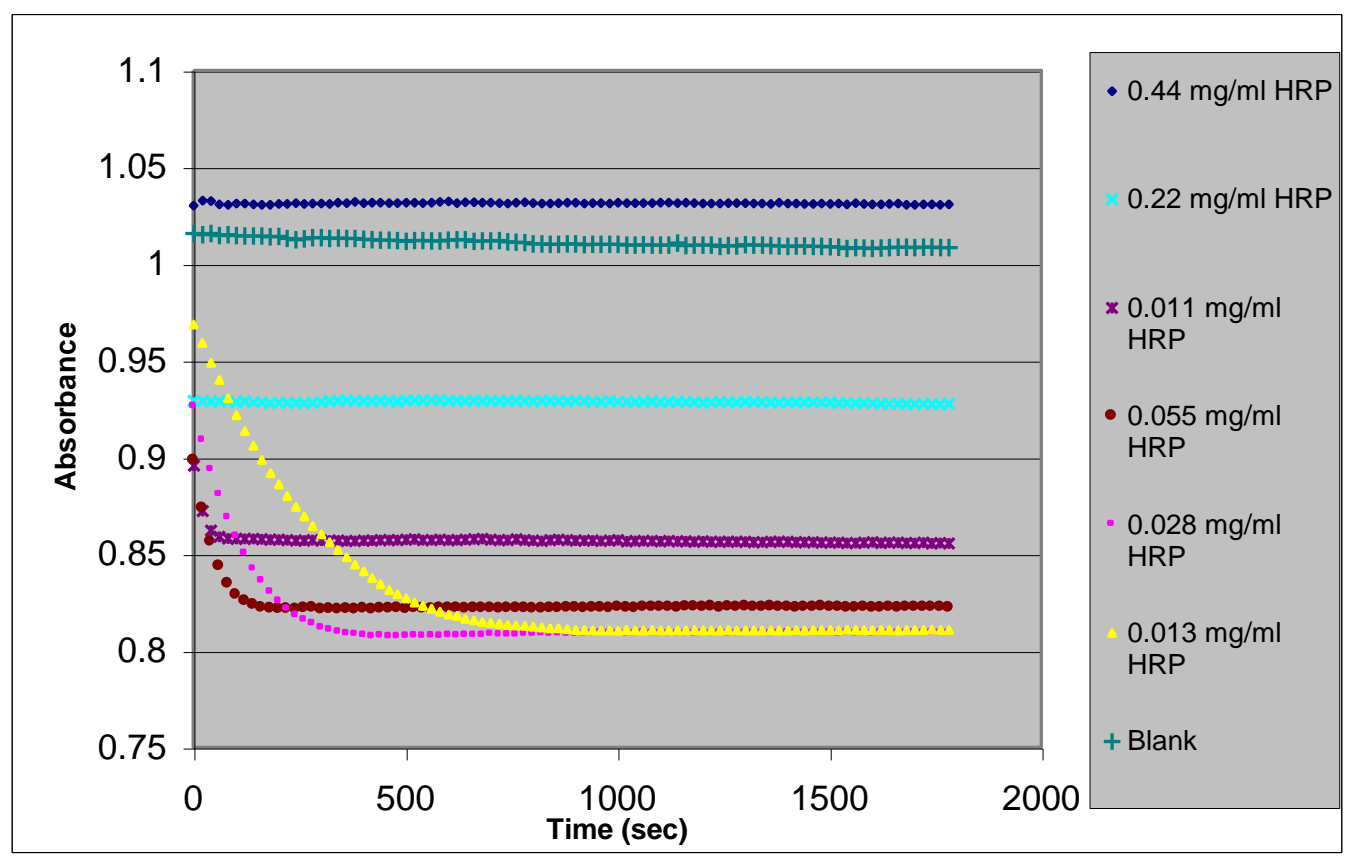


Figure SI3: Reaction rate in $\mathrm{pH} 6.0$ citrate buffer as a function of Type I HRP concentration for a chlorite concentration of $2.0 \mathrm{mg} \mathrm{L}^{-1}$.

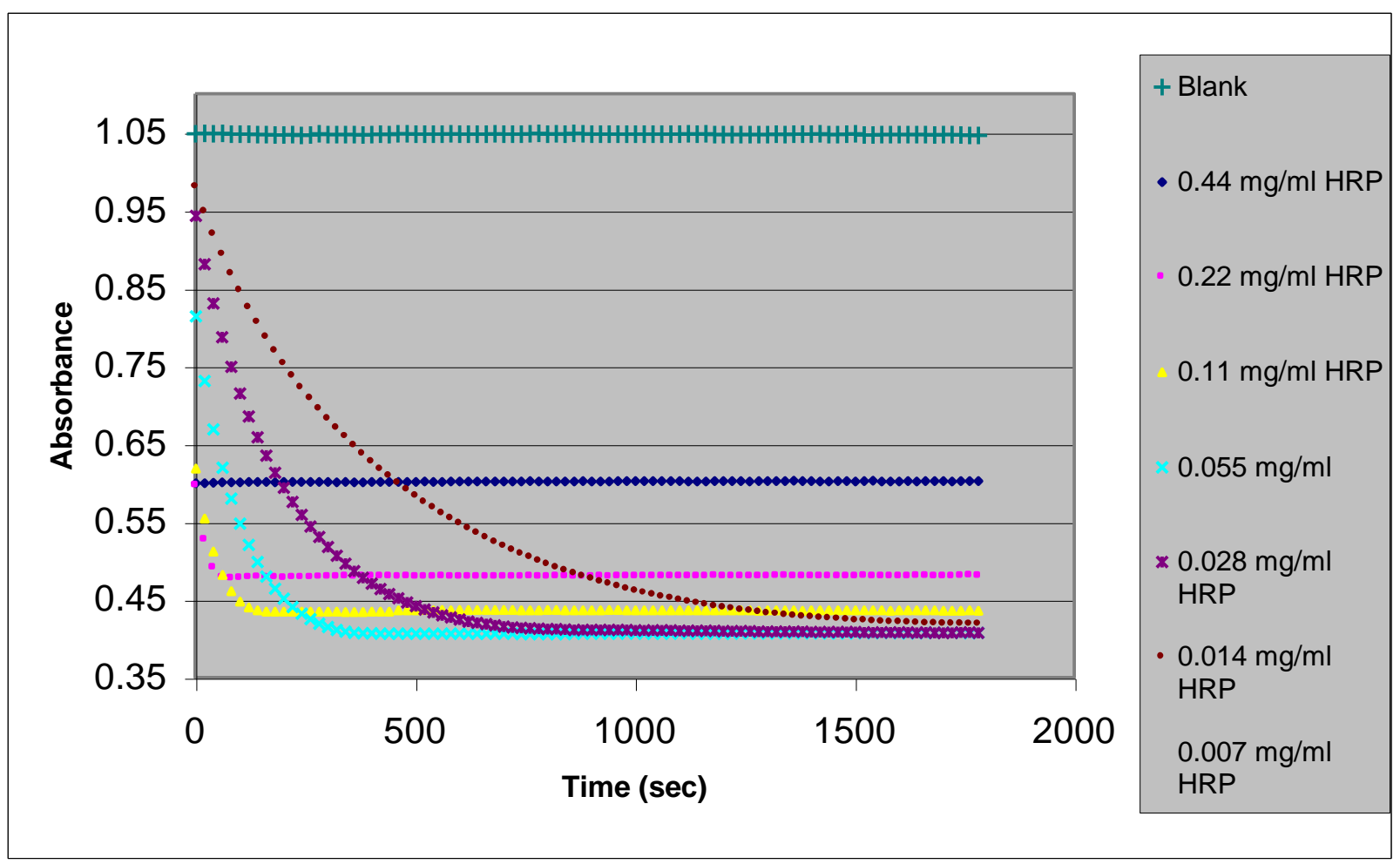


Figure SI4: Reaction rate in $\mathrm{pH} 6.0$ citrate buffer as a function of Type II HRP concentration for a chlorite concentration of $1.0 \mathrm{mg} \mathrm{L}^{-1}$.

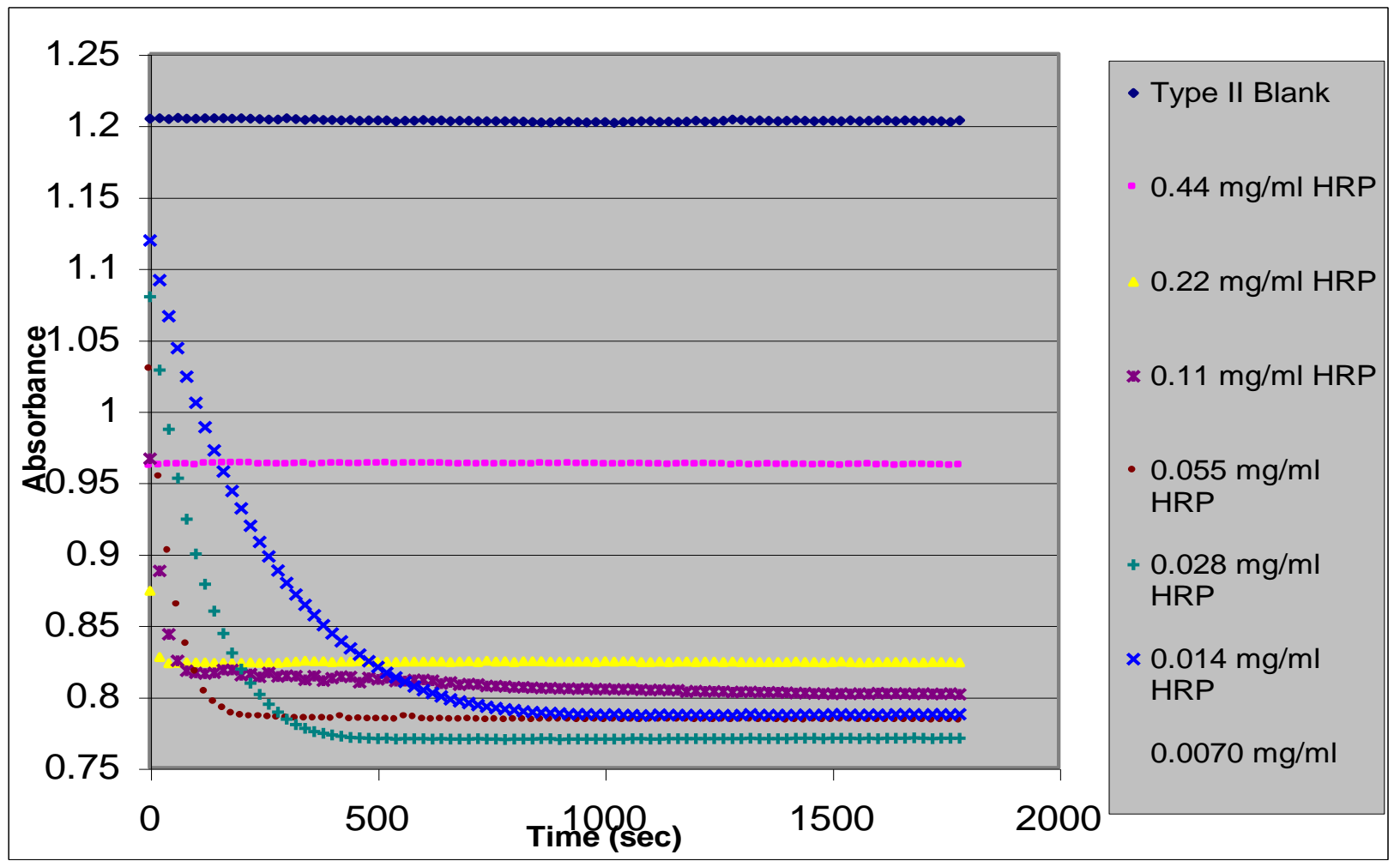


Figure SI5: Reaction rate in $\mathrm{pH} 6.0$ citrate buffer as a function of Type VIA HRP concentration for a chlorite concentration of $1.0 \mathrm{mg} \mathrm{L}^{-1}$.

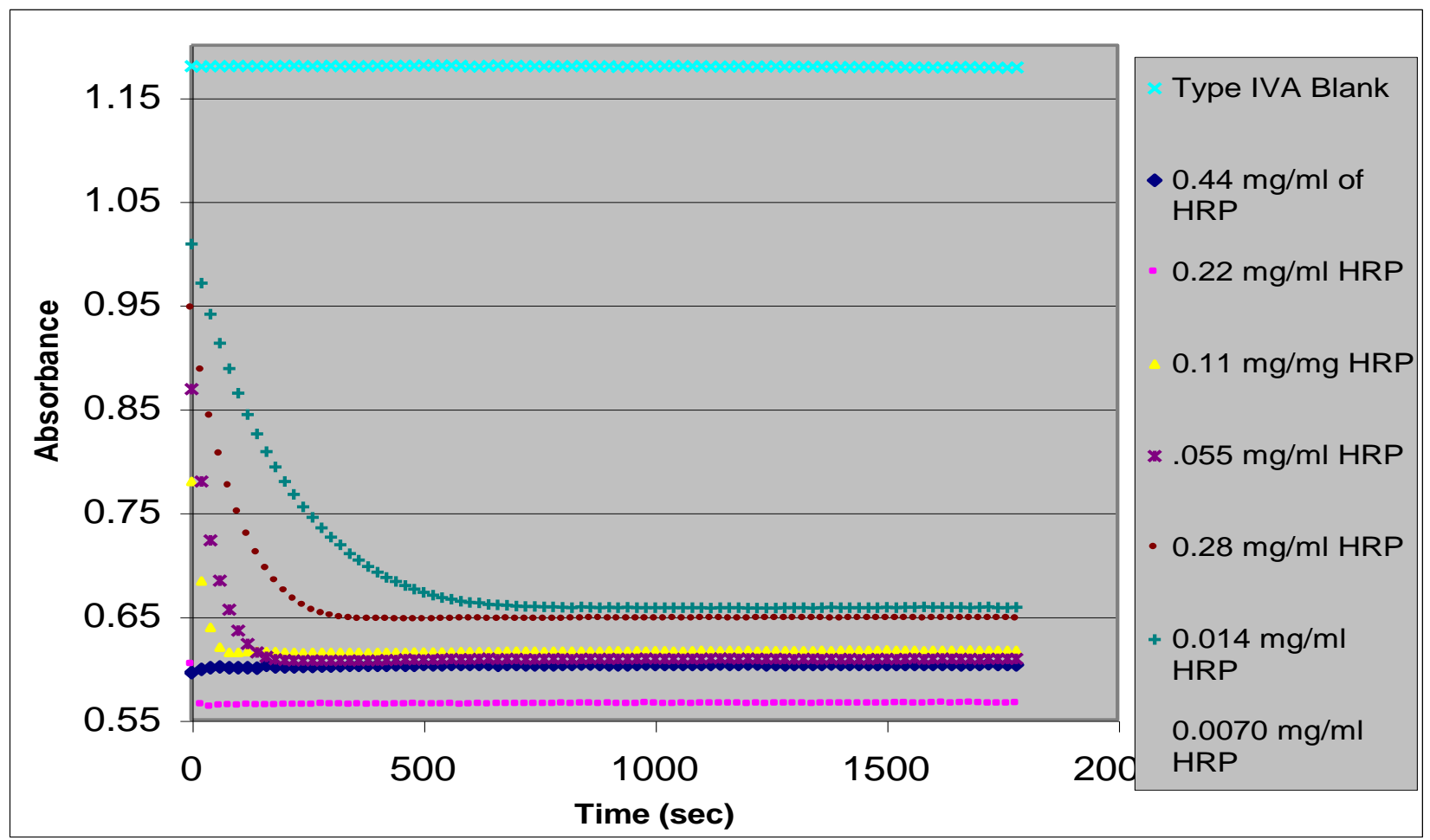


Figure SI6: Type I HRP $\left(0.028 \mathrm{mg} \mathrm{mL}^{-1}\right)$ reaction rate as a function temperature for a chlorite concentration of $1.0 \mathrm{mg} \mathrm{mL}^{-1}$.

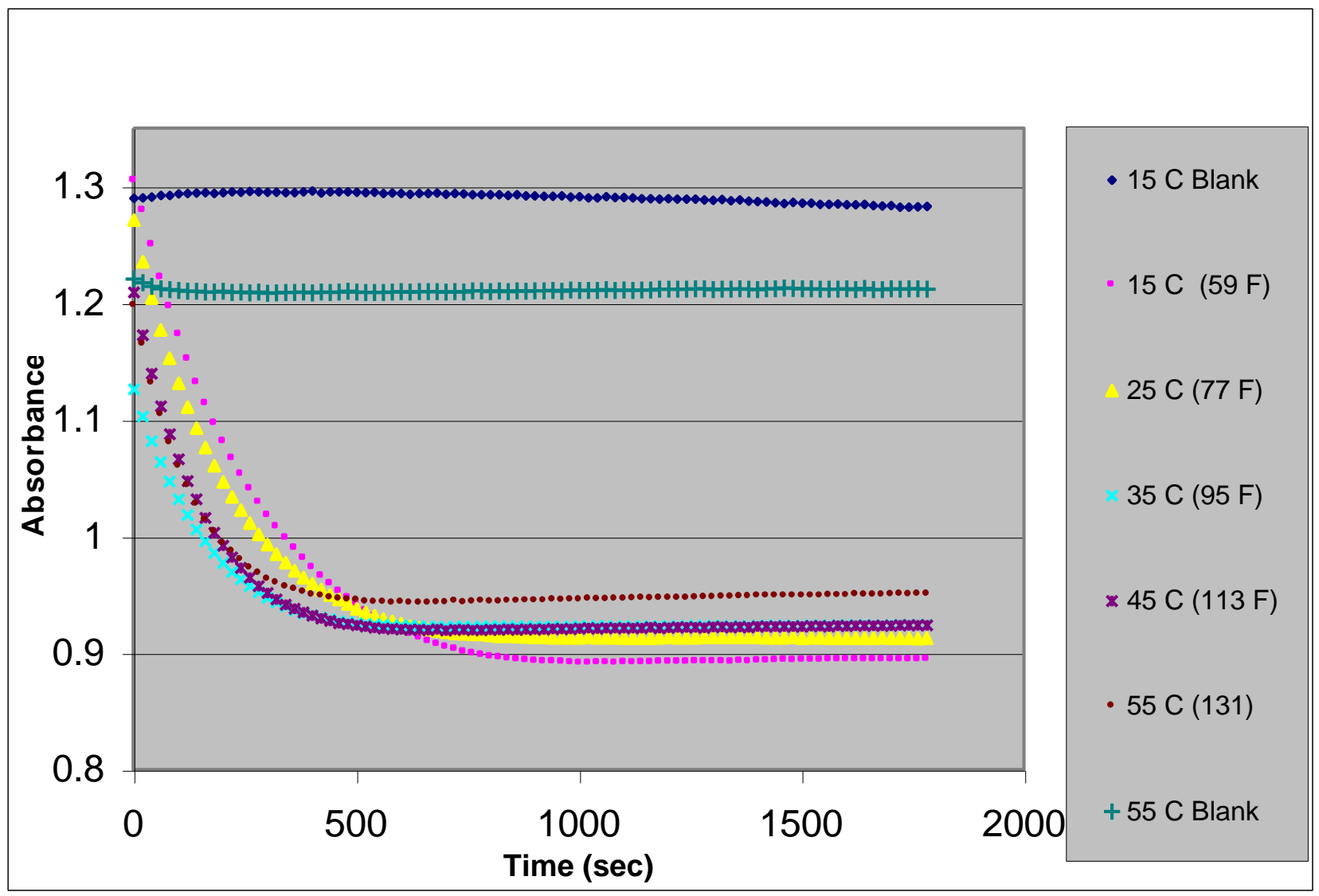


Figure SI7. The dependence of method sensitivity for the chlorite and chlorine dioxide analyses as a function of LGB concentration. All absorbances measured in a 5-mm pathlength cell, but multiplied by two to be consistent with data presented elsewhere. Error bars are \pm one standard deviation based on triplicate measurements.

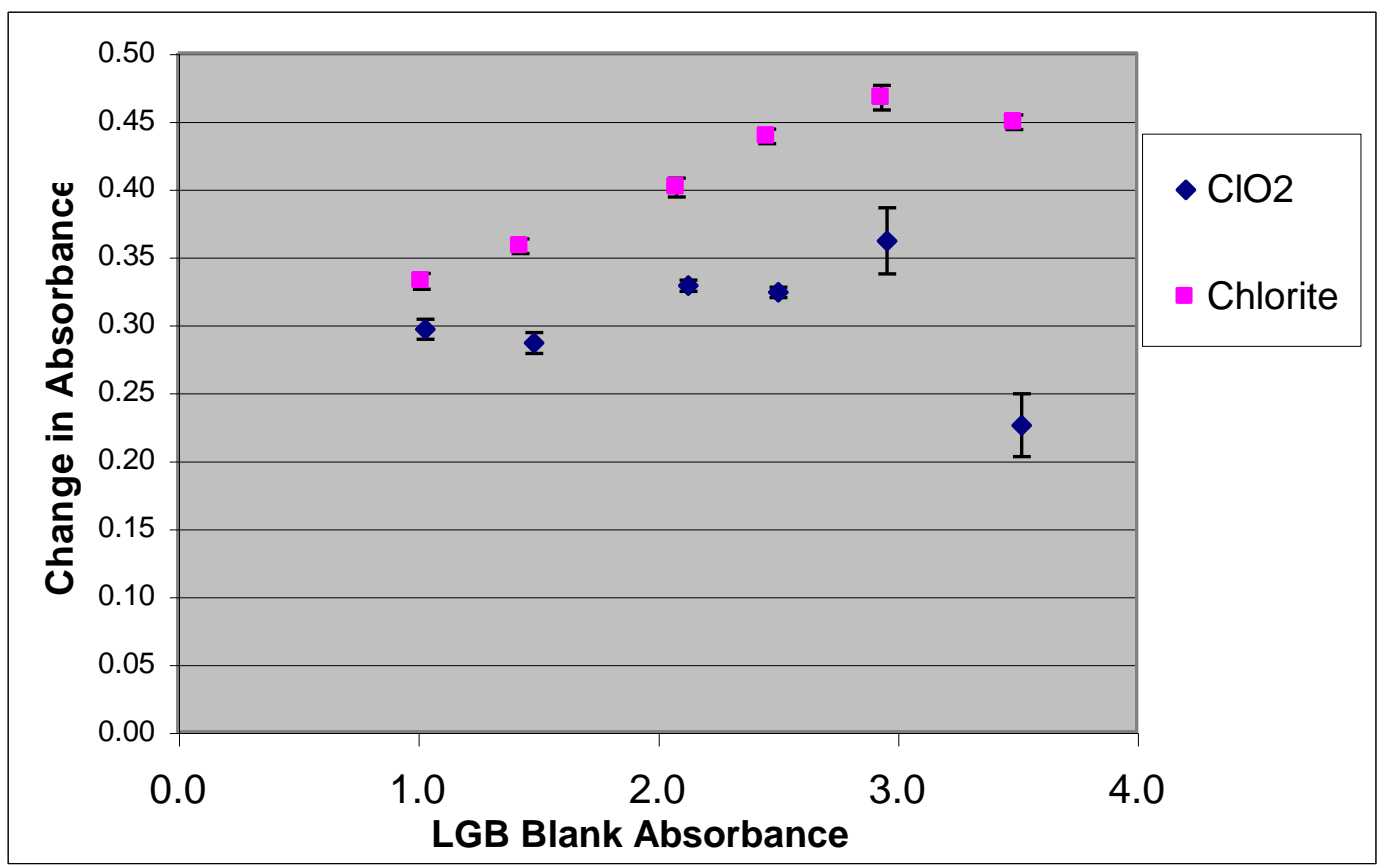

